\title{
CRIMINAL PROCEDURE IN ISRAEI- SOME COMPARATIVE ASPECTS *
}

\author{
ELTAHU HaRnon $\dagger$
}

\section{Preliminary}

In July 1965 a new comprehensive law on criminal procedure was passed by the Knesset, the Israeli Parliament. It is now appropriate to point out some of the main features of criminal procedure in Israel and some of the more important changes introduced by this new law.

Until 1965, the rules of criminal procedure in Israel, like the rules in other branches of the law, were composed of remnants of the Ottoman law, legislation of the British Mandate and amendments introduced by the State of Israel. Now for the first time, the field of criminal procedure has been treated by the legislature in a thorough and comprehensive manner. With the exception of legislation in matters requiring immediate attention, the policy of the Israeli legislature has been to concentrate on one province of the law at a time. Thus, law reform has been based on a close examination of comprehensive proposals, after substantial periods of preliminary work. The new law replaces eighteen former enactments of Ottoman, Mandatory and Israeli origin and includes almost 230 articles. It covers almost the whole road of the criminal process from arrest to appeal.

\section{The Judiciary and Criminal Jurisdiction}

Although the English common law pattern served as a model for the administration of justice in Palestine, there was a striking departure-the absence of a jury which was continued in Israel. The jury system, whether for preliminary inquiries or for the trial itself, was never adopted; even in criminal cases, courts are constituted of professional judges only. This eliminates some of the problems of defining the respective functions of judge and jury. ${ }^{1}$

* I am indebted to Professor Anthony G. Amsterdam for his guidance and advice.

$\doteqdot$ Dr. Jur., Senior Lecturer, Hebrew University of Jerusalem; 1965/66 Bicentennial Fellow in Criminal Law and Administration at the University of Pennsylvania Law School.

1 The distinction between law and fact is still of practical importance, e.g., in its bearing on the exercise of appellate jurisdiction, the principle being that courts of appeal generally review only questions of law as distinguished from findings of fact. That distinction is also pertinent in regard to several rules of pleading and evidence. 
The judges of the three main courts-the Supreme Court, the District Courts and the Magistrates' Courts-are appointed for life. Tenure terminates only upon death, resignation or retirement (on pension at an age fixed by statute). Provision is also made for the removal of a judge from office, but this is feasible only on recommendation of a special court of discipline appointed by the judiciary itself for each particular case. ${ }^{2}$ The President of the State nominates the judges; in practice, he acts upon the recommendation of an Appointments Committee which consists of nine members-three judges of the Supreme Court, and two representatives of the Government, the Parliament and the Bar. ${ }^{3}$

The ordinary courts are organized in a hierarchy of three levels. There is one Supreme Court sitting in the capital, four District Courts and twenty-five Magistrates' Courts.

The jurisdiction of the criminal courts follows the classification of the penal law which recognizes three classes of offenses: contraventions, misdemeanors and felonies. A contravention is an offense punishable by imprisonment for not more than one month or, in case of fine, 200 Israeli pounds ( $\$ 67$ ); a misdemeanor, the "intermediate" offense, is punishable by imprisonment of more than one month and less than three years; a felony is one punishable by death ${ }^{4}$ or a term of imprisonment exceeding three years.

Magistrates' Courts are courts of first instance for contraventions and misdemeanors. The more severe offenses-feloniesare brought to the District Courts which also have appellate functions in reviewing the Magistrates' Courts' judgments. The Supreme Court has only appellate jurisdiction in criminal matters. ${ }^{5}$

As a rule, a trial court consists of a single judge, ${ }^{\mathfrak{b}}$ an appellate court, of three judges. A similar bench of three District Court judges

2 No case of such removal has yet occurred.

3 See the Judges Law, 5713-1953, 7 Laws of the State of Israel 124 (Authorized Translation from the Hebrew).

4 As to the death penalty, it should be noted that since 1954 the penalty for murder is life imprisonment, Criminal Law Amendment [Abolition of Death Penalty for Murder] Law, 5714-1954. Death may be imposed only for certain offenses against the security of the state if committed in time of emergency or during hostilities, and for convictions of murder under the Nazis and Nazi Collaborators (Punishment) Law, 5710-1950. 4 Lazes of the State of Israel 154 (Authorized Translation from Hebrew). In the case of Eichmann, the Jerusalem District Court decided that the death sentence for violation of this law was not mandatory, but depended on the discretion of the court. Criminal Case 40/61, Att. Genn. v. Adolf Eichmann, session no. 121, Publication of the Center of Information 284-85 (in Hebrew, Jerusalem 1962).

5 The Supreme Court also sits as a High Court of Justice-a court of first instance in matters not within the province of any other court or tribunal. In this capacity, it operates mainly as an administrative court, dealing with petitions against official persons and bodies, such as orders of mandamus, prohibition, certiorari, habeas corpus and prerogative remedies. See the Courts Law, 5717-1957, 11 Lawes of the State of Israel 157 (Authorized Translation from the Hebrew).

6 In special cases, the number of judges sitting on the bench may be increased. 
is required in trials of the more serious crimes: offenses punishable by death ${ }^{7}$ or by imprisonment for a term of ten or more years.

\section{The Adversary System}

Following the English pattern, criminal procedure in Israel is essentially accusatory and adversary. The state prosecutor and the defendant have equal standing before the court. ${ }^{8}$ The accused benefits from the presumption of innocence and the right of silence. It is for the parties and not the court to submit all the relevant evidence at their disposal ${ }^{\circ}$ and to examine the witnesses through direct examination, cross-examination and re-direct examination. The role of the court is predominantly passive, although it will occasionally put questions to the witnesses in order to clarify what seems obscure or examine the witnesses after the parties have concluded. ${ }^{10}$

The judge is not obliged to look down on the arena, to keep silent and be secretive as the sphinx up to the day of rendering judgment. On the other hand, we object to that system wherein some judges walk in the arena to and fro, asking, inquiring and admonishing, actually conducting the trial by themselves. ${ }^{11}$

The Israeli judge is supposed to be slightly more active than the English judge-he is not restricted to "keeping the ring" between the disputing parties. This tendency emerges from the rules for the introduction of evidence on the initiative of the court.

Even in England the judge may call a witness not called by either the prosecution or the defense, without the consent of either, if he finds it necessary in the interest of justice. But after the close of the case or the defense, the calling of such a witness must be limited to cases where something has arisen "ex improviso, which no human ingenuity could foresee." 12 In no case may a witness be called by the judge after the conclusion of the summing up. ${ }^{13}$

In the United States, the prevailing rule and practice seems to be that the judge has no burden or duty of adducing evidence, though

7 See note 4 supra.

8 See High Court 156/56 Shor v. Att. Genr., 11 Piskei Din 285, 297-99. [Piskei Din ("Judgments")- Law reports of the Supreme Court of Israel, published by the Ministry of Justice].

9 See Criminal Appeal 38/61 Itzchak, 16 Piskei Din 514, 528-30.

10 The new law $\$ \$ 156,157$.

11 Criminal Appeal 20/49, Za'arur, 3 Piskei Din 13, 26.

12 King v. Harris [1927] 2 K.B. 587; Regina v. Cleghorn [1967] 1 All E.R. 996. But see Regina v. Tregear [1967] 1 All E.R. 989. R. 226.

13 Regina v. Owen [1952] 2 Q.B. 362 C.C.A.; R. v. Wilson [1957] 41 Crim. App. 
he has the power to do so. It is in the discretion of the trial judge to call a witness on his own motion, if his failure to make use of this power has a tendency to suppress some of the relevant facts. It is generally felt that this discretion ought to be cautiously exercised only in exceptional cases. ${ }^{14}$

The courts in the Mandatory period pointed out that because of the broader language of the law in Palestine, they had more latitude in making use of their initiative provided that it was carefully and sparingly used. ${ }^{15}$ In a leading case in 1961, the Supreme Court of Israel affirmed a conviction based, inter alia, on the initiative taken by the trial court in calling a witness after the case for the defense had been concluded. ${ }^{16}$ In the opinion of the Court, although the system is adversary and the prosecution carries the burden of proving guilt beyond any reasonable doubt, it is still the duty of the judge to ascertain the truth. The Supreme Court, however, directed that this power should be used only in exceptional cases, when the court is satisfied that no miscarriage of justice is caused to the defendant and stated that it is the duty of the court to give the parties an opportunity to cross-examine the court's witness. ${ }^{17}$ The legislature-as reflected

14 United States v. Marzano, 149 F.2d 923 (2d Cir. 1945) ; State v. Loveless, 140 W. Va. 875, 87 S.E.2d 273 (1955) ; Hill v. Commonwealth, 88 Va. 633, 14 S.E. 330 (1892) ; 9 WrgMoRe, EvmENCE, $\$ \$ 2483-84$ (3d ed. 1940). See also PauLsen AND Kadish, CRIMINat LAw aNd ITs PRocesses $1137-42$ (1962).

A more active appraisal of the role of a judge, however, has been expressed by Mr. Justice Frankfurter in a dissenting opinion. In a res ipsa loquitur case he noted that the failure of a trial judge to call, on his initiative, an available eye-witness is a legitimate ground of appeal and, therefore, the cause should be remanded for further proceedings :

While a court room is not a laboratory for the scientific pursuit of truth, a trial judge is surely not confined to an account, obviously fragmentary, of the circumstances of a happening . . . when he has at his command the means of exploring them fully, or at least more fully, before passing legal judgment. A trial is not a game of blind man's buff; and the trial judgeparticularly in a case where he himself is the trier of the facts upon which he is to pronounce the law-need not blindfold himself by failing to call an available vital witness simply because the parties, for reason of trial tactics, choose to withhold his testimony. Federal judges are not referees at prize fights but functionaries of justice.

Johnson v. United States, 333 U.S. 46, 53-54 (1948). See also HALL \& Muet.Ler, Crtastanar law and Procedure 962 (2d ed. 1965):

The trend has been toward a strengthening of the role of the judiciary, not for the purposes of making the judge an active or potential partisan representative of the people in the case, but for the purpose of preventing abuses by the litigants and fostering the ascertainment of truth. This purpose has been all too easily concealed under the "sportive" system.

15 Criminal Appeals 68/29 Zenet, 1 Palestine Law Reports 418; 71/31 Salem, 1 Palestine Law Reports 594; 16/38 Chalik, 1938 (1) Appelbom 131; 126/41 Melikian, 8 Palestine Law Reports 478; 112/43 Daksh, 143 Annotated Law Reports 686.

16 Criminal Appeal 153/60 Shefer, 15 Piskei Din 263.

17 The dissenting Justice noted that the majority opinion could well lead to a relaxation of the adversary system, "for it is usually not carelessness which prompts judges to overstep their bounds and perform the functions of the prosecutor, but their distaste for the adversary system itself, on the grounds that it is not conducive to arriving at the real truth." 15 Piskei Din at 276. 
in the new law ${ }^{18}$ and the attendant parliamentary debate ${ }^{10}$ - seems to have similar views on this matter.

In the new law, the powers of the court to call evidence on its initiative have been clarified and even enlarged. One may view it as a slight departure from the traditional passivity attributed to an English judge. ${ }^{20}$

\section{The Prosecution ${ }^{21}$}

The State's control and command of criminal proceedings is characteristic of the criminal law and a sign of its public nature. ${ }^{22}$ The constitutional responsibility of the executive to enforce the criminal law in Israel has been vested by law in the Attorney General. $\mathrm{He}$ has the primary powers to initiate and to discontinue criminal proceedings (by the nolle prosequi or nol pros). ${ }^{23}$

Although one of the members of the Government is the Minister of Justice, the Attorney General is neither a member of the Govern-

18 Summoning of witnesses

95. . . the court may also summon witnesses of its own motion. . . .

Evidence of court's own motion:

150. When the parties have concluded their evidence, the court may, either upon the application of a party or of its own motion and if it deems it necessary, direct that witnesses be called, even where the evidence of such witness has already been heard by the court, and that any other evidence be submitted.

Evidence on court's own motion:

163. Where a witness has been called of the court's own motion under sec. 150 , the court shall give the parties an opportunity to cross-examine him in such order as it may determine.

19 When sections 95 and 150 of the new law were discussed at the Knesset, one member said, inter alia,

Do not limit the judge. If it seems to him . . . that one link [of the chain]

is missing and he thinks he knows where to find it, what should he do?

Should he acquit the accused? Let the judge conduct an investigation to elicit the facts to ascertain the truth .... [Other] members ... have argued that our judges are not dumb, they make the first steps in this [active] direction. This law comes to encourage that development, and I see in sec. 95 and 150 a further step in this direction; not a revolution, but a natural and desirable development of the position of the judge . . . .

Divrei HaKnesset (Records of Knesset Proceedings), session no. 492 of July 5, 1965, p. 2429, per D. Bar-Rav-Hai, M.K. (in Hebrew).

20 Speaking on the function of the judge in England, Dr. Williams says :

[A]n overspeaking judge is no well tuned cymbal .... The classic advice

to a newly appointed judge is that he should take a sip of holy water in his

mouth at the beginning of a case and not swallow it until the evidence on both sides has been heard.

Wimitars, The Proof of Gullt 26 (3d ed. 1963).

21 This part is largely based on High Court 156/56 Shor v. Att. Gen., 11 Piskei Din 285 and on a special opinion prepared for the Government in 1962 by a committee composed of two Justices of the Supreme Court and one advocate headed by Mr. Justice Agranat, now the President of the Supreme Court [hereinafter cited as the Lawyers Committee]. The task of the lawyers committee was to clarify the powers of the Attorney General in the enforcement of the criminal law and advise to what extent-if at all-he is subject to the supervision of the Minister of Justice or the Government. (1955).

22 See, e.g., Williams, The Definition of Crime, 8 Current Iegal Problems 107

23 See the new law $\$ \$ 9-10,202$. 
ment nor a member of the Knesset (Parliament). ${ }^{24}$ To be eligible for his office, he has to have the same qualifications as those required for becoming a Justice of the Supreme Court. Upon the recommendation of the Minister of Justice, the Government is authorized to appoint, as well as to dismiss, a person as Attorney General. His office is within the Ministry of Justice. The Minister may assume the powers which the law vests in the Attorney General, but this authority has been used by Ministers of Justice only when the Attorney General could not function, e.g., when he was outside the country.

It has been clearly pointed out that in discharging his functions in the enforcement of the criminal law, the Attorney General is not subject to instructions of the Minister of Justice or the Government. "The law speaks directly to him and he is personally clothed with duties, responsibilities and obligations." 25 Carrying the responsibility to protect the public interest, the Attorney General ought to exercise his discretion as prosecutor in a quasi-judicial way and he has to keep in mind the following general considerations:

Initially, it is obvious that any person who violates the criminal law should be punished. The prosecutional machinery should not be used to harass the individual in vain in unfounded cases. Special circumstances may justify his not prosecuting even if technically there was a breach of the law. In other words, despite a provable violation of the law, prosecution should be declined due to a possible adverse effect on the public interest or because of exceptional conditions related to the offender. ${ }^{26}$

Thus it is clear that the European legality principle, under which the prosecutor is obliged to prosecute if the evidence points to a prima facie case, does not apply in Israel where the prosecutor acts at his discretion. ${ }^{27}$

The Attorney General has to report to the Minister of Justice and to the Government on his actions and ought to consult them

24 In this respect, he differs from the Attorney General in England. On the Attorney General in England, see Devitin, The Criminal Prosecurion in England 20-24 (1958); Edwards, The Law Officers of the Crown, chs. 10-12 (1964); MacDernott, Protectron From Power UNDer English Law 25-41 (1957); Robson, Control of Public Officers, Discretion by Minister, 10 MODERN L. REv. 70 (1947).

25 This is Professor Robson's phraseology adopted by the lawyers committee. Robson, supra note 24 , at 71 .

26 See the opinion of the Lawyers Committee 6 (in Hebrew).

27 The difference, however, is in fact less striking than it appears to be. The discretionary system is based on the assumption that "the criminal process ordinarily ought to be invoked ... when it appears that a crime has been committed and there is a reasonable chance of apprehending and convicting the perpetrator . . . If the legislature has decided that certain conduct is to be treated as criminal, the decision makers at every level of the criminal process are expected to accept that basic decision as a premise for action." Packer, Two Models of the Criminal Process, 113 U. PA. L. REv. 1, 7-8 (1964). 
particularly on matters of political, security or other public significance. However, his ultimate decisions are his own; he has to maintain a complete independence and exercise his own judgment and his own discretion. Even the Supreme Court, sitting as High Court of Justice with general powers to supervise the executive, will ordinarily not order the Attorney General to initiate or to discontinue criminal proceedings; that is within the discretion of the Attorney General. The Court will intervene only in the exceptional case of mala fides, when the Attorney General's act is totally inconsistent with the public interest. $^{28}$

Formally, the State is the prosecutor represented by a plaintiffthe Attorney General or one of his staff, the State Attorney, one of the District Attorneys or their assistants, or any other person specially authorized by the Attorney General. All of these officials are appointed State employees. In Magistrates' Courts, the prosecution may be conducted by police officers specially qualified, "provided that the Attorney General may direct that any class of cases or any particular case or proceedings shall be conducted by some other prosecutor." 29

In a limited number of minor offenses, the law enables any person to initiate directly the criminal process by filing a "private complaint." In such cases, the prosecution will also be conducted by the complainant unless the District Attorney intervenes and takes over the prosecution. ${ }^{30}$ The nolle prosequi power of the Attorney General, however, includes the power to discontinue prosecution of a private complaint.

In all other cases of "non-private" offenses, when the police and prosecution decide not to investigate or not to initiate criminal proceedings, the complainant may apply to the Attorney General for review and the Attorney General's decision is final. ${ }^{31}$

The function of the Attorney General ${ }^{32}$ is a very important, complicated and delicate one in the administration of the criminal law, ${ }^{33}$ and therefore ought to be above party politics. The structure of the office of the Attorney General, as described above, enhances that independence. Some have doubted whether it is desirable to vest such

28 See High Court 119/59, Reichbach, 13 Piskei Din 1486; High Court 4/64 Wagner v. Att. Gen., 18 Piskei Din 29.

29 The new law $\S 10(b)$. See also the new law $\S \S 9,10(a), 75(2)$.

30 See the new law $\S \S 62-66$.

31 See the new law \$\$ 52-61.

32 See Kaplan, The Prosecutional Discretion-A Conment, 60 Nw. U.L. REv. 174,180 (1965).

33 "The discretionary power exercised by the prosecuting attorney in initiation, accusation and discontinuance of prosecution gives him more control over an individual's liberty and reputation than any other public official." Note, Prosecutor's Discretion, 103 U. PA. L. REV. 1057 (1955). 
enormous powers in an executive official in spite of his independent position in exercising his discretion. The modes of his appointment and removal, in particular, worries critics who have suggested some judicial supervision of his decisions. In this context, the American law and practice in nol pros is certainly worth considering. In a few jurisdictions, the prosecutor retains the absolute power to discontinue criminal proceedings, similar to the powers of the Attorney General in England and in Israel, but several states have vested this authority entirely in the discretion of the court. An intermediate system has been adopted by other states, requiring court approval for the entry of a nol pros. ${ }^{34}$ All these modes of judicial control deal only with the nol pros power. They do not limit the prosecutor's discretion in his primary decision whether to institute criminal proceedings initially.

A similar intermediate procedure has been suggested in the parliamentary debate in Israel by one Member of the Knesset and by the Israeli Criminology Association. ${ }^{35}$ However, the Knesset did not accept the amendment. The only change introduced by the new law is a requirement that the Attorney General's stay of proceeding be made to the court by written notice, specifying the reasons. ${ }^{36}$

\section{Civil Action and Criminal Proceedings}

A criminal act, in addition to being a breach of public order, may inflict injury on a private person. Similar to the law in some continental countries ${ }^{37}$ and in the early days in America, ${ }^{38}$ the Ottoman law in Palestine enabled such an injured person to join the criminal trial as a civil party. In case of conviction, the court had civil powers to award damages upon proof of civil liability and the extent of injury. Various disadvantages involved in this joint procedure caused it to fall into disuse and it is explicitly abolished by the new law. ${ }^{39}$

Civil injuries may, however, be finally settled incidental to criminal conviction and sentence without the injured person's becoming a formal party to the criminal proceedings. After conviction, the court may order the accused to pay to the injured person an amount not exceeding 1,500 Israeli Pounds $(\$ 500)$ for every offense, as

$34 \mathrm{Id}$. at $1066-67,1071-72,1077-81$. As to police discretion to invoke the criminal process, see LAFAVE, ARREST, part II (1965).

35 See Divrei HaKnesset [Records of Knesset Proceedings], session No. 493 of July 6,1965 , p. 2443 per I. H. Klinghoffer, M.K.

36 The new law $\$ 202$.

37 For a recent analysis of such a joint procedure in France, see Larguier, The Civil Action for Danages in French Criminal Procedure, 39 TUL. L. Rev. 687 (1965). 38 See Hilkey, Legal Devetopments in Colonial Massachusetts, 1630-1686, 142 (1910).

39 The new law $\S 208$. 
compensation for the damage or suffering caused to him. For purposes of enforcement, the order is regarded as a civil judgment. ${ }^{40}$ Most of those injured by criminal acts will institute separate and independent civil proceedings thus avoiding the monetary limitation.

Following the English rule in Hollington v. Hewthorn, ${ }^{41}$ the courts in Israel held that in civil actions evidence of previous criminal proceedings, arising out of the same set of facts, is inadmissible; even a conviction has no probative value. In response to repeated criticism, ${ }^{42}$ a proposal to modify the law for tort actions has been approved in Israel by a reform committee appointed by the Minister of Justice. The proposal provides that convictions should be admitted in actions in tort as prima facie evidence of the facts upon which they are founded. Subject thereto, new facts may be proved pertaining to various defenses, including contributory negligence. ${ }^{43}$

\section{Preliminary Inquiry and Discovery}

A significant aspect of pre-trial procedure in Israel is the parallel development of a gradual abolition of the judicial preliminary inquiry and the broadening of discovery.

\section{The Preliminary Inquiry and the Grand Jury}

The preliminary inquiry has undergone three main stages. In 1924, Mandatory legislation followed the English model and required a preliminary inquiry to be conducted in public by a magistrate in all felony cases. His task was not inquisitorial, initiating the investigation and collecting evidence and depositions, but rather accusatory, dis-

40 Criminal Law Amendment [Methods of Punishment] Law, 5714-1954, 57231963, \$§ 31-32. Compare some American penal laws that provide as an additional penalty the imposition of a fine proportioned to the civil injury, the fine to be collected as any criminal fine, but then turned over to the victim. See MAYERS, THE AMrerican Legar System 12, at n.5 (Rev. ed. 1964). Another mode of compensating the victim of an offense may be found in the practice of conditioning probation on the restitution to the victim of the loss or damage he suffered. The authority to impose such a "civil" condition is granted to the criminal courts either expressly by statute or by a general wide discretion in regard to terms of probation. See Best \& Birzon, Conditions of Probation-An Analysis, 51 Gro. L.J. 809, 818, 826-28 (1963).

41 [1943] K.B. 587 (C.A.) ; [1943] 2 All E.R. 35.

42 See Cross, Evidence, $376-77$ (2d ed. 1963) ; Yoran, The Effect of Criminal Convictions on Civil Wrong Actions, 20 Hapraklit 322 (1964) [in Hebrew, with an English summary] ; Johnson, Res Judicata: $A$ Comparative Study, 18 CURRENT I EGAL Problems 81 (1965).

43 In the United States and in most jurisdictions, the rule is similar to the English one where there is no identity of parties in the criminal and civil actions. In some states, however, convictions serve as prima facie evidence in the subsequent civil action. Recently, the Supreme Court of Pennsylvania took an extreme view holding that proof of conviction is conclusive evidence of the facts in issue. Hurtt v. Stirone, 416 Pa. 493, 206 A.2d 624 (1965), noted in 65 Colum. L. Rev. 1941 (1965) ; 39 TeMr. L.Q. 109 (1965). See also Annot., 18 A.L.R.2d 1287. 
charging a judicial function by examining and reviewing the results of the prosecution's investigation, the incriminating material assembled by the police. ${ }^{44}$

In $1958,{ }^{45}$ the preliminary inquiry was abolished for all cases except the more serious felonies, those punishable by imprisonment for a term of ten years or more. Even in those cases, the preliminary inquiry was to be held only if requested by either the accused or the prosecutor. A District Court judge took the place of the Magistrate. His task was not to determine whether the accused was guilty, but only whether the evidence afforded a prima facie justification for charging the accused. A further purpose of the preliminary inquiry was to aid defense trial preparation by disclosing to the accused the nature of the evidence against him. ${ }^{46}$

The new law completely abolishes the preliminary inquiry, ${ }^{47}$ so that from now on, even in the most serious crimes, the trial itself comes immediately after the completion of the investigatory stage, conducted independently by the prosecution. ${ }^{48}$

In the United States, the initiation of criminal proceedings in serious crimes ordinarily must be by indictment. ${ }^{49}$ The grand jury process in the United States and the preliminary inquiry in Palestine and Israel had, in general, a common purpose and function-to guard against unwarranted prosecution by serving as an effective "filter" through which unjustified accusations cannot pass. ${ }^{50}$ They both have

44 See Trial Upon Information Ordinance, 1924-1925, $\$ 16,18$; I BeNTwICE, LAwS OF PALESTINE 416 (1926).

45 Criminal Procedure Amendment [Investigation of Felonies and Causes of Death] Law, 5718-1958, 12 Lazes of the State of Israel 66 (Authorized Translation from the Hebrew).

46 See Criminal Appeal 216/56, Yathom, 11 Piskei Din 592, 594 ; High Court 124/58 Att. Gen. v. The Inquiring Judge, 13 Piskei Din 5.

47 The new law $\$ 226$ (11).

48 It may be interesting to note that in England the proceedings before examining justices recently were criticized strongly by Lord Devlin, as an archaic time-wasting ceremonial. See The London Times, Dec. 10, 1965. Under a new procedure recommended by two Members of Parliament, the defendant would be given, in advance, copies of statements from the prosecution's witnesses. He could then opt either for committal proceedings, as at present, or could inform the court that he was willing to be committed for trial on the basis of the written statement. See id. Feb. 17, 1966. That proposal seems to resemble the law in Israel in 1958-65. See text accompanying note 45 supra and notes 65-66 infra.

49 Among the guarantees specifically covered in the Bill of Rights is the right to be accused by a grand jury. U.S. CoNst. amend. V. See Costello v. United States, 350 U.S. 359 (1956). This guarantee, however, does not bind the states, so that a state may abolish indictment by grand juries. Hurtado v. California, 110 U.S. 516 (1884).

50 See Orfiesd, Criminal Procedure From Arrest to Appeal 144-46 (1962). It should be noted, however, that the decision of these two supervisory bodies may still differ when we compare the legitimate considerations. When the evidence indicates a prima facie case, the grand jurors are still competent to hand down a "no bill," if they believe that community sentiment opposes prosecution. This "prerogative of mercy, which all lay participation is intended to add to a professional administration of criminal justice," was not granted to or expected from the professional judge who held a preliminary inquiry or his predecessor-the committing magistrate. Hall. \& Mueller, Criminal Law and Procedure 932 (2d ed. 1965). 
powers to coerce people to testify and submit evidence, but otherwise their modus operandi is significantly different. Unlike the preliminary inquiry, the grand jury is a secret ex parte proceeding. Only the prosecutor and sometimes a stenographer are present when witnesses testify. The defendant is not entitled to notice of a grand jury investigation. Only the evidence for the prosecution is heard and that without cross-examination. ${ }^{51}$ One whose conduct is being investigated by the grand jury has no right to petition the grand jury, ${ }^{52}$ to appear before it, personally or by counsel, or to have witnesses testify in his favor. ${ }^{53}$ While the prosecuting attorney has, in fact, unlimited access to grand jury records and minutes, the defendant in most states has no right of inspection, but may be allowed to inspect in the judge's discretion. For many years the general tendency of the courts has been not to allow the defendant to inspect grand jury documents, following the opinion of Judge Learned Hand that ". . . no judge of this court has granted it [a request to inspect the minutes of the grand jury] and I hope none ever will. . .." 54 However, in a few states, like California, ${ }^{55}$ every defendant receives a transcript of grand jury minutes as a matter of course upon indictment.

Elsewhere, it seems that different views have lately emerged. "Many courts are recognizing the need for pretrial discovery of grand jury minutes and the necessity for allowing their introduction at the trial for purposes of impeachment and refreshing recollection," ${ }^{56}$ particularly in cases involving indigent defendants.

\section{Discovery in Favor of the Defendant}

The reception of English criminal procedure in Palestine carried the premise that an accused should have some access to the evidence

51 The nature of its [the Grand Jury's] function, unlike an adversary proceeding, contemplates that it will hear from many sources uninhibited by the strict rules of evidence applicable in a trial and untested by the traditional adversary tools such as cross examination. Obviously, public officers are charged with a high duty to screen out unreliable witnesses, but the critical and final place to detect perjury is on trial when the witness must face the accused before the world and expose himself to the rigors of cross examination and other hazards including contempt.

Coppedge v. United States, 311 F.2d 128, 132 (D.C. Cir. 1962).

52 In a few states, defense counsel may submit written views for consideration by the grand jury, although elsewhere this would be regarded as jury tampering punishable by contempt proceedings.

53 Indeed, it has been argued that this one-sided process weakens the functioning of the grand jury as an independent check on the prosecuting attorney. E.g., ". . . a grand jury may become a pliant prosecutor's tool, rubber-stamping bills of indictment." Excerpts From the Proceedings in State v. Culombe 29 (Amsterdam Ed.) (2d Draft mimeo, 1965). But see id. at n.6; Hall \& MUEILER, op. cit. supra note 50, at 932 .

54 United States v. Garsson, 291 Fed. 646, 649 (S.D.N.Y. 1923)

55 See Louisell, MODERN CALIForNia Discovery, § 13.05, at 395 (1963).

56 Calkins, Grand Jury Secrecy, 63 Micr. L. Rev. 455, 490 (1965). See also Note, Disclosure of Grand Jury Minutes to Challenge Indictments and Impeach Witnesses in Federal Criminal Cases, 111 U. PA. L. REv. 1154 (1964). 
collected by the prosecutor. That was not an ancient common law notion: ${ }^{57}$ but rather the fruit of reform achieved in England during the 19 th and early 20 th centuries. ${ }^{58}$

However, the extent of access was very much limited and a matter of judicial discretion. Israeli legislation only recently established a statutory right to inspect the evidence of the prosecution. ${ }^{59}$

In the Mandatory period, a general right of access to the police file did not exist. The courts, however, recognized that a person charged with a felony should be entitled to inspect previous written statements of witnesses whose names appear on the back of the charging paper and to use these statements at trial in the course of crossexamining those witnesses. The balance of convenience may decree that such access should be given before, rather than at the trial. ${ }^{60}$ Similarly, the court directed that the accused or his advocate or expert is entitled, under proper safeguards, to have access to the exhibits upon which the prosecution's expert based his opinion." Failing to afford the defense such access at the trial was considered a sufficient ground for reversal of convictions. ${ }^{62}$

In a leading case in $1951,{ }^{63}$ the Supreme Court of Israel refused to consider itself bound by the limited common law modes of discovery. That judgment broadened the possibilities of access to prose-

57 The Court of the King's Bench denied a request of an accused to inspect the Attorney General's report of the interrogation of witnesses in India, because "There is no principle or precedent to warrant it ... and if we were to grant it, it would subvert the whole system of criminal law. The practice ... shows it to be clear that this defendant is not entitled to inspect the evidence on which the prosecution is founded, till the hour of trial." $R$. v. Holland, 100 Eng. Rep. 1248, 1249, 1250 (1792) ; "The 'non-possumus' tendency of the common law courts to refuse any measure of discovery before trial is seen at its extreme phase in criminal cases." 6 WIGMORE, EVIDENCE, § 1863 (3d ed. 1940). See also id. \$1845.

58 The defendant in England is generally entitled to a preliminary hearing where he may be present and represented by counsel and cross-examine the prosecution's witnesses. Records of these proceedings are available to the defendant. Thus, it may serve as an effective discovery method for the defendant. Although a general right of pre-trial discovery can hardly be found, a great deal of informal discovery is apparently the customary practice. See LoUISEII, op. cit. supra note 55 , at $381-85$; WIIShere, Criminal Procenure 33-40 (4th ed. 1961). For a critical view on this state of law in England, see Napley, Problems of Effecting the Presentation of the Case for a Defendant, 66 Colum. L. Rev. 94, 103-06 (1966).

59 It should be noted that, in practice, the defendant or his counsel may occasionally be permitted to have access to the prosecution's material upon a "gentlemen's agreement" in an informal way, with no need of a court order, particularly when a prosecutor regards opposing counsel as worthy of trust and courtesy; but we are concerned with the right of inspection: to what extent is the defendant entitled to discovery. One commentator on this subject remarks: "Probably many prosecutors will not, in any case, yield more than they must" Loursers, op. cit. supra note 55, at 374 n.6.

60 See High Court 33/37 Sheinzwit v. Inspector General of Police, 4 Palestine Law Reports 221, 224; Criminal Appeal 162/28, Sa'adeh Abu Rashid, 1 Palestine Law Reports 348.

61 High Court 33/37, sispra note 60 , at 225

62 Criminal Appeal 35/50, Malka, 4 Piskei Din 429, 432-33, 436.

63 High Court 147/50 Tzinder v. Head of Police Investigation Dep., 10 Psakim 'Elyon 236. [Psakim "Elyon ("Supreme [Court] Decisions")-Law reports of the Supreme Court of Israel, published by the Israel Bar Association.] 
cutorial material in two respects: first, the court directed that prior to trial, even in the case of charges below a felony, the prospective court is empowered to grant inspection at its discretion. Second, whenever the right to inspect does exist, it extends not only to the depositions of the prosecution's witnesses, but to any relevant material in the possession of the police, except matters the disclosure of which is contrary to public policy (e.g., items that concern the security of the State or names of police informers). However, the Supreme Court did not find any compelling reason to enable inspection, in felony charges, at an even earlier stage than the preliminary inquiry. In the view of the court, the latter process served as an appropriate vehicle for discovery. ${ }^{64}$ During the preliminary inquiry, the court added, permission to inspect may be granted by the examining judge. A law of 1958 for the first time established a statutory right of discovery. ${ }^{65}$ Any person accused of a felony ${ }^{66}$ may inspect the evidence in the possession of the District Attorney. The right to inspect was advanced in time, starting when the charge is received.

The new law of 1965 follows the same liberal policy of criminal discovery and even broadens it. ${ }^{67}$ The right to inspect is extended to cover cases of misdemeanors. ${ }^{68}$ The accused or his counsel has a right to make copies of the investigatory material. ${ }^{69}$ As long as the accused has not waived his right to discovery, the prosecutor may not produce material in court or call any witness that the accused has not been given reasonable opportunity to examine. ${ }^{70}$ The saving clauses retain the governmental privilege or duty not to disclose confidential material or information pertinent to the security of the state, but subject to the prohibition not to submit it as evidence. ${ }^{71}$ The right to discovery does not apply "to evidence intended to rebut any plea of the accused which the prosecutor could not have anticipated, or evidence produced to explain the absence of a witness, or pertaining to any other formal matter not material to the determination of the charge." 72

64 We have seen (text accompanying notes 44-46 supra) that at the preliminary inquiry there was never any doubt that the defendant has the right to attend and take an active part.

65 Criminal Procedure Amendment [Investigation of Felonies and Causes of Death] Law, 5718-1958, 12 Lazes of the State of Israel $\$ 6$.

66 For the classification of offences in Israel see text accompanying note 4 supra.

67 The new law, tit. C.

68 See note 65 sipra.

69 The new law $\$ 67$.

70 The new law $\$ 70$.

71 See The new law $\$ \$ 71,74$. Compare Jencks v. United States, 353 U.S. 657, 671 (1957). "The Government can invoke its evidentiary privileges only at the price of letting the defendant go free."

72 The new law $\$ 73$. Incidentally, the names of the prosecution's witnesses are known to the accused since they ought to be included in the statement of charge. See The new law $\$ 75(6)$. 
An observer of the new law might well ask whether the broadened right of discovery justifies the complete abolition of the preliminary inquiry. In view of the adversary character of the preliminary inquiry in Israel, the Supreme Court indicated that cross-examination at the preliminary inquiry enabled the accused to elicit further facts from those who gave depositions to the police-facts that may be essential to the preparation of his defense. Such additional information cannot be gathered from a "passive" inspection of the prosecution's file. ${ }^{73}$

Furthermore, with the abolition of the preliminary inquiry, pretrial judicial supervision over the administrative action of the prosecutor also disappeared, even in the most serious crimes. The importance of this function of the judge who held the preliminary inquiry was emphasized by the Supreme Court in $1959 .{ }^{74}$

As to rules of discovery in the United States governing federal criminal trials, ${ }^{75}$ no report or statement given to an agent of the United States need be produced until the witness has testified on direct examination and the trial judge has determined that the report or the statement is relevant. Then the government must produce it on motion by the defense; if the government fails to produce it, that witness's testimony at the trial must be stricken. ${ }^{76}$

Prior to trial in the United States, there is no established right of the defendant to inspect all relevant evidence in the possession of the prosecution. Indeed, until recently, defendants who demanded it were generally unsuccessful. In rejecting such applications, the main reasons given were the fear that early discovery would lead to subornation of perjury, tampering with witnesses and suppression of evidence. ${ }^{77}$ However, commentators on this subject point to the rapid movement of the law toward early discovery. ${ }^{78}$ 24-25.

73 See High Court 124/58, Att. Gen. v. The Inquiring Judge, 13 Piskei Din 5,

74 See id. at $19-20$.

75 Jencks Act, 18 U.S.C. $\$ 3500$ (1964). An English lawyer has recently suggested "that some provisions based upon the concept inherent in the Jencks Act in the United States would materially assist the administration of justice in this country [England]." Napley, Problems of Effecting the Presentation of the Case for a Defendant, 66 Colum. L. Rev. 94, 104 (1966).

76 That enactment was designed to avoid any broader application of discovery that might have been given to the decision of the Supreme Court in Jencks v. United States, 353 U.S. 657 (1957). See also Note, 34 Geo. Wasn. L. Rev. 92, 98 (1965). A defendant also has the right at trial to demand experimental or test examination results from the prosecution. See HaLL \& MuELLER, op. cit. supra note 50 , at 925 . That right is now advanced to apply also prior to trial in federal cases according to Rule 16.

77 See, e.g., State v. Tune, 13 N.J. 203, 210, 98 A.2d 881, 884 (1953) ; People ex rel. Lemon v. Supreme Court, 245 N.Y. 24,156 N.E. 84 (1927). See also 6 WIGMORE, EVIDENCE, $\$ 1845$ (3d ed. 1940).

78 See, e.g., State v. Johnson, 28 N.J. 133, 145 A.2d 313 (1958). Also see Fletcher, Pretrial Discovery in State Criminal Cases, 12 Stan. L. Rev. 293 (1959). 
In the federal courts, the main provision for discovery is Rule 16 of the Federal Rules of Criminal Procedure. ${ }^{79}$ It abandons the requirement that the defendant show "that the items sought may be material to the preparation of his defense" and that his request be reasonable, as to three classes of items: statements made by the defendant, the results of physical or mental tests and testimony before a grand jury. These are revealed as of right. For all other items the requirements of reasonableness and materiality are retained. ${ }^{80}$ Some federal courts in recent years have applied the Fourteenth Amendment in this field, holding that nondisclosure of important exculpatory evidence violates due process of law. ${ }^{31}$ The increasing willingness to grant discovery seems to derive, inter alia, from a gradual re-evaluation of the role of the prosecutor. Since the "combat" theory of criminal procedure is less accepted today, a trial can no longer be considered "a game of wits and skill." 82 It is a recognition that the prosecuting attorney has a dual role which motivates the demand for a wide extension of discovery. Discovery is perhaps but one means for reducing the general disparity between the investigating powers of the state and the defendant. ${ }^{83}$

79 Because of the restrictive interpretation given to Rule 16 and due to a preponderance of recent legal literature in favor of increasing the range of permissible discovery, several amendments to the rule were proposed. The most recent revision became law at the end of March 1966, upon approval by the Supreme Court. 355 F.2d 184, 186-87 (1966). Discovery extends to all relevant material "within the possession, custody or control of the government, the existence of which is known, or by the exercise of due diligence may become known to the attorney of the government." FED. R. CRIM. P. 16.

80 See also FED. R. CRTM. P. 17(c), particularly the last sentence:

The court may direct that books, papers, documents or objects designated in the subpoena be produced before the court at a time prior to the time when they are to be offered in evidence and may upon their production permit the books, papers, documents or objects or portions thereof to be inspected by the parties and their attorneys.

81 See United States ex rel. Meers v. Wilkins, 326 F.2d 135 (1964); Note, The Prosecutor's Constitutional Duty to Reveal Evidence to the Defendant, 74 YALE I.J. 136 (1964); Note, The Duty of the Prosecutor to Disclose Exculpatory Evidence, 60 ColuM. I. REV. 858 (1960).

82 To require the disclosure to an adversary of the evidence that is to be produced, would be repugnant to all sportsmanlike instincts. Rather permit you to preserve the secret of your tactics, to lock up your documents in the vault, to send your witness to board in some obscure village, and then, reserving your evidential resources until the final moment, to marshal them at the trial before your surprised and dismayed antagonist, and thus overwhelm him.

Such was the spirit of the common law; and such in part it still is . . . It did regard the concealment of one's evidential resources and the preservation of the opponent's defenseless ignorance as a fair and irreproachable accompaniment of the game of litigation.

6 WIGMORE, EvIDENCE, § 1845, at 375-76 (3d ed. 1940).

83 See Application of Kapatos, 208 F. Supp. 883, 888 (S.D.N.Y. 1962) ; Goldstein, The State and the Accused: Balance of Advantage in Criminal Procedure, 69 Yale L.J. 1149, 1152, 1172-73, 1180-85, 1192-97 (1960). But see the oft-quoted dictum of Judge Learned Hand in United States v. Garsson, 291 Fed. 646, 649 (S.D.N.Y. 1923):

Under our criminal procedure the accused has every advantage. While the prosecution is held rigidly to the charge, he need not disclose the barest out- 


\section{Discovery in Favor of the Prosecution}

The gradual increase of pre-trial discovery measures in favor of the defendant raised the analogous problem whether a corresponding right ought not to be granted to the government. If discovery is designed to reduce surprises and contribute to more accurate factfinding, the very same argument may be put against the defendant for a reciprocal discovery unless compelling reasons prevent such an extension.

The new law in Israel does not include any provision on this matter. In England, it seems that disclosure of evidence is completely one-sided in favor of the accused. However, to balance the scales, Dr. Glanville Williams has suggested that the law be amended so that the accused will be required not only to give advance notice of the defenses of alibi and insanity and lists of his witnesses, but also to reveal to the prosecution the documents of the defense including depositions of the defense witnesses. ${ }^{84}$ In the United States, the subject is under current development, particularly due to a significant decision of the supreme court of California in $1962 . .^{85}$

Many states have provided various pleading devices to obtain advance knowledge of the defenses of alibi and insanity and of defense's proposed witnesses prior to trial. ${ }^{86}$ It seems, therefore, that today one can hardly agree with a sweeping statement that a defendant "need not disclose the barest outline of his defense." 87

In the California case referred to above, ${ }^{88}$ the prosecution moved for the production by defendant of all medical reports and the names and addresses of all physicians whom defendant intended to bring as his witnesses or who had treated defendant prior to trial. The trial court granted the motion and the California Supreme Court affirmed with one qualification: the defendant is required to reveal what he in-

line of his defense. $\mathrm{He}$ is immune from question or comment on his silence; he cannot be convicted when there is the least fair doubt in the minds of anyone of the twelve. Why in addition he should in advance have the whole evidence against him to pick over at his leisure and make his defense, fairly or foully, I have never been able to see. . . . Our dangers do not lie in too little tenderness to the accused. Our procedure has been always haunted by the ghost of the innocent man convicted. It is an unreal dream. What we need to fear is the archaic formalism and the watery sentiment that obstructs, delays and defeats the prosecution of crime.

See also LouIsEx, op. cit. supra note 55 , at 370-72.

84 Williams, Advance Notice of the Defence, CrIM. L. Rev. 548 (1959).

85 Jones v. Superior Court, 58 Cal. 2d 56, 372 P.2d 919 (1962).

86 See HAIL \& MUELLER, op. cit. supra note 50, at 926; LOUISEIL, op. cit. supra note 55 , at 416 .

87 United States v. Garsson, 291 Fed. 646, 649 (S.D.N.Y. 1923) (L. Hand, J.). See note 83 supra.

88 See note 85 supra. 
tends to introduce in evidence for his defense. Faced with the principle against self-incrimination, with the rule that a defendant in a criminal case has a right to stand mute, the court answered that as this evidence will necessarily be revealed at the trial, learning the identity of it in advance "merely enables the prosecution to perform its function at the trial more effectively." 89

On July 1, 1966, the Supreme Court adopted the new Rule 16(c) which requires the court to permit mutuality. The court is now permitted to condition disclosure by the prosecution on a corresponding disclosure by the defendant. ${ }^{90}$

\section{The Charge and the Plea}

The new law establishes a unique form of written charge and modifies the form of pleas on the merits. Until 1965, the traditional English form of accusation was used, emphasizing the offense, each one being embodied in a separate "count." A count comprised two parts: the "statement of offense," and the "particulars of offense." Prosecutors were required to follow the models provided in a supplement, e.g., in manslaughter:

Statement of Offense-Manslaughter, contrary to section 212 of Criminal Code Ordinance, 1936.

Particulars of Offense-A.B., on the - day of at —unlawfully killed C.D.

89 Jones v. Superior Court, $58 \mathrm{Cal} .2 \mathrm{~d}$ at $61,372 \mathrm{P} .2 \mathrm{~d}$ at 922 . According to the dissent, giving the prosecution such access to the evidence of the defendant, violates the fundamental guarantees against self-incrimination. It undermines the time-honored position of the defendant in a criminal case.

If the majority opinion were sound, it would mean logically that the prosecu-

tion could serve interrogatories upon defendant demanding to know whether

or not he intends to rely on an "affirmative" defense, what it is, and what

evidence he has to support it. I am not willing to see fundamental consti-

tutional rights emasculated in this fashion.

Id. at 66. For further discussions of this case and its implications see LourserI, op. cit. supra note 55, at 434-36; Louisell, Criminal Discovery and Self-Incrimination: Roger Traynor Confronts the Dilemma, 53 CALIF. L. REv. 89 (1965) ; Traynor, Ground Lost and Found in Criminal Discovery, 39 N.Y.U.I. REv. 228 (1964) (the author being Chief Justice Traynor who wrote the opinion of the court in the Jones case).

90355 F.2d 184, 187 (1966). See also Proposed Amendments, Federal Rules of Criminal Procedure, 34 F.R.D. 411, 422 (1964). On this proposal Professor Amsterdam remarks

". . to the extent that the Constitution requires prosecutorial disclosure of information to the defense in advance of trial it is dubious that the defendant may be required to waive his privilege against self-incrimination as the condition of access to the information." Amsterdam (Ed.), supra note 58, at 31 n.13. "If discovery, by itself, of information in the possession of the defendant would violate the privilege against self-incrimination, is it any less a violation if conditioned on the defendant's exercise of the opportunity to discover evidence? May benefits be conditioned on the abandonment of constitutional rights?" Mr. Justice Douglas' Statement, dissenting from the new Rule 16(c), 355 F.2d 208, 209 (1966). 
The new law does not speak in terms of "counts," "statement of offense" and "particulars of offense," and model forms are no longer provided. Instead, the defendant receives a narrative statement of the facts constituting the offense, so as to give him a complete and concrete picture of the circumstances of the case.

The document, now called "statement of charge," still contains, inter alia, the allegation of law violated, yet it is not considered a central element of the charge, but merely an additional means of clarification. When the defendant is called upon to plead to the charge, the question is no longer whether he pleads "guilty" or "not guilty," but rather whether he admits or denies all or any of the facts alleged in the statement of charge. He may also plead additional facts. ${ }^{91}$

These innovations are an attempt to simplify the charging paper, to make it less technical and better understood by the layman. They are based on the assumption that it is easier and perhaps more logical to invite the accused's reaction to an allegation of fact than to an allegation of law, thereby leaving the issue of guilt for the judge to decide.

A lucid and accurate charge, it has been said, will avoid surprises at the trial and will enable the accused to prepare his defense more adequately. ${ }^{92}$ Such certainty will also protect the accused from being twice put in jeopardy. ${ }^{93}$

In this context, the general provision against meaningless technicalities seems pertinent. Section 211 of the new law states that ordinarily a technical defect in the form of any document shall not affect

91 The new law $\$ 136$.

Pleas of accused

[T] he court shall ask the accused to plead to the charge; the accused may remain silent and if he pleads, may in his plea admit or deny all or any of the facts alleged in the Statement of Charge and may also, whether or not he has made any admission as aforesaid, plead additional facts. The response of the accused may be made by his counsel.

92 See Nuasser, Criminal Appeal 146/51, 6 Piskei Din 308; Kaizer, Criminal Appeal 88/58, 12 Piskei Din 1628, 1634 (1958).

93 See Kiryati, Criminal Appeal 242/63, 18 Piskei Din, III, 477, 486 (1963). Section 2 of the new law provides:

Double Jeopardy

No person shall be tried for an act constituting an offence in respect of which

he has previously been acquitted or convicted. . . .

Section 168 says:

Conviction of Several Offences

The court may convict an accused of all or any of the offences of which his guilt has been disclosed or the facts proved, but shall not pass upon him more than one sentence for the same act.

Again, it is a factual test, the sameness of act rather than the sameness of offense.

On the forms of indictment or information introduced by the Federal Rules of Criminal Procedure and particularly the short form indictment, see Rule 7 and Holtzoff, A Criminal Case in the Federal Couts, 1963 FED. R. CRIM. P. 1, 9-10. See also State v. Greer, 238 N.C. 325, 77 S.E.2d 917 (1953) ; HALL \& MUELLER, op. cit. supra note 50 , at $934-35$. 
the validity of the proceedings unless a miscarriage of justice is likely. ${ }^{94}$ That provision follows the policy directives laid down by the President of the Supreme Court when the first criminal appeal after independence reached the Supreme Court in Israel:

Criminal proceedings should not become a chess game where one wrong move determines the fate of the game. The function of criminal procedure is to see that justice shall be done. It is important that the people should realize that their judges go into the chamber, where crime and punishment are explored, and do not stay in the vestibule dealing only with the statement of Charge, whether proper or defective. . . .95

\section{SUMMING-UP}

Concluding this comparative study, it may be noted that in spite of the differences between the American and the Israeli legal systemsparticularly the nonexistence of juries in Israel-they have much in common in criminal procedure. This similarity undoubtedly derives from the influence of the English common law on the law of both countries. Even after the termination of the British Mandate in Palestine, Israel, of her own free will, has continued to follow the Anglo-American model in procedure, carefully considering the introduction of modifications. The new law does not reveal any change in principle in that policy.

We have seen the basic resemblance in the position of the defendant, the presumption of innocence and the respective functions of court and parties, operating in adversary systems. The analysis of the powers of the Attorney General pointed out the problem of control shared by both countries, as to whether or not his decisions should be subject to any judicial supervision.

The gradual abolition of the preliminary inquiry, the changes introduced in the forms of the written charge and in the plea and the proposal that certain criminal judgments shall have probative value in civil proceedings arising out of the same set of facts-all these may serve as significant instances of a general trend in Israel to shorten and simplify legal proceedings.

The law of criminal discovery indicated independent parallel developments of case law and legislation in both countries to meet the

94 The Federal Rules of Criminal Procedure include similar general directions for effective enforcement of the criminal law without regard to harmless errors that have no bearing on the question of the defendant's guilt or innocence. See FED. $R$. CrIMr. P. 2, 52 (a) ; Holtzoff, supra note 93, at 3-4.

95 Silvester, Criminal Appeal 1/48, 1 Psakim 'Elyon 513, 525 (1948). See note 63 supra. See also Cohen, Criminal Appeal 321/62, 17 Piskei Din 846, 851 (1962). 
need of information for a fair and adequate defense. The corresponding possibility of directly or indirectly forcing a defendant to disclose his defense prior to trial is an interesting innovation in the United States. It may call for further study coupled with a reconsideration of the traditional position of the defendant in the AngloAmerican and Israeli legal systems. 